\title{
How can migration serve adaptation to climate change? Challenges to fleshing out a policy ideal
}

\author{
FRANÇOIS GEMENNE*†キ AND JULIA BLOCHER*‡§ \\ *Hugo Observatory, Department of Geography - University of Liège, Liège, Belgium \\ E-mail: f.gemenne@ulg.ac.be \\ +University of Versailles (CEARC - UVSQ), Versailles, France \\ ¥Sciences Po Paris, 27 rue Saint-Guillaume, 75007 Paris, France \\ E-mail: francois.gemenne@sciencespo.fr, julia.blocher@sciencespo.fr
}

$\S$ United Nations University Office at the United Nations, 2 United Nations Plaza, New York, NY

10016, USA

E-mail: blocher@unu.edu

This paper was accepted for publication in November 2016

\begin{abstract}
Migration continues to be pictured in public debates as a failure to adapt to changes, while policymakers explore adaptation measures as a means to reduce migration pressures, and scholars have contended that migration processes exist within a larger framework of strategies for adapting to damaging climate change impacts. So what are the impacts of migration on the adaptive capacities and vulnerabilities of the origin and host communities, as well as of the migrants themselves? The objective of this conceptual and methodological paper is to identify possible different options for research into the consequences of migration for adaptation. The first section reviews how the migration-adaptation nexus has been addressed in the literature, confirming the potential of human mobility to build resilience and to increase adaptive capacities within complex and potentially maladaptive processes. The next section explores the potential impacts of migration that need to be studied, from three main vantage points: the migrants themselves, the community of origin, and the community of destination. A final section weighs the possible approaches and suggests solutions that may exist to advance empirical study of the migration-adaptation area nexus, so that it can address not just the causes, but also the consequences of migration in the context of environmental changes.
\end{abstract}

KEY WORDS: migration, adaptation, climate change, migration governance, displacement, resilience

\section{Introduction}

$\mathrm{O}$ ne of the founders of migration studies, Ravenstein (1885), described migration as 'life and progress', whereas a sedentary population meant 'stagnation'. Other authors in the field have characterised migration as a process aimed at adjusting to changes (including Ratzel, Wolpert, Huntington).

This idea has been revived, with a broader dimension, in the context of the impacts of climate change. Scholars have extended their view that sudden and recurrent environmental factors influence secular seasonal and short-term mobility (Chhetri 1987; Findley 1994) to account for the potential of climate changes to produce migration outside of 'usual' migration patterns (Glantz 1991; Rosenzweig and Hillel 1993). Some suggest that climate change has caused the displacement of whole societies and the subsequent fall of empires (Orlove 2005; Magnan et al. 2016). Climate change erodes the resilience of communities, modifying not only the number of migrants but the characteristics of pre-existing patterns of migration as well. Rural resource-based livelihoods are the most directly affected (Obokata et al. 2014). People in vulnerable environments are highly exposed, for example, in mountain (Afifi et al. 2014; Milan and Ho 2014; Milan et al. 2015) or island communities (Barnett 2001; Mortreux and Barnett 2009; IPCC 2007 2014).

Though migrants are often portrayed as victims in the context of climate change, empirical evidence also shows that in the face of environmental and climatic stress, migration is a common household strategy aimed at supporting basic needs and livelihoods (Hampshire 2002; Foresight 2011; Piguet 
2013). Yet a UN review of national policy views and priorities for international migration revealed that most governments tend to focus migration policies on reducing pressures to migrate, managing authorised movements, and controlling irregular flows (UN DESA 2013). This is reflected in the dominant public and political narratives of migration, through which policymakers are incentivised to oversimplify migration as an issue of competition and tensions (Boswell et al. 2011; Blocher 2016), while linking migration to endemic conflict, disease, crime and resource scarcity (McLeman 2014). Policymakers often view climate change adaptation measures and sustainable development in the larger sense as a means to reduce migration pressures, particularly for rural and hazard-exposed populations (Clemens 2014).

Additional empirical work is needed (Foresight 2011). There is growing consensus among scholars that migration itself serves as part of the positive adaptation strategies adopted in the context of environmental and climatic change (Bardsley and Hugo 2010; Black et al. 2011a; McLeman and Smit 2006). It can be a way to reduce population pressures in places prone to climate risks (Lonergan 1998; McLeman and Hunter 2010), while diasporas provide important resources to help communities adapt and respond to climate change, through economic and social remittances and more (de Haas 20072008 2010; Levitt and Lamba-Nieves 2011). Although discussed often, the application of migration in the field of climate change adaptation has not been adequately examined. Furthermore, the policy apparatus capable of delivering the potential of migration has not yet been developed (Bettini and Andersson 2014). A key challenge today is to flesh out the relationship between migration and adaptation processes in the context of climatic changes. This article seeks to provide a perspective on this from the field of migration studies, and begins to address managed migration as a new tool for climate change adaptation policy, and one that transforms mobility into a positive exercise.

\section{Overview and contribution of this article}

Since the late 2000s, migration has been increasingly characterised as a potential adaptation strategy in response to climate change (Black et al. 2011b; Webber and Barnett 2010). Yet, despite a proliferation of empirical studies on the topic (cf. Piguet 2010 2013), a number of fundamental gaps remain in its theoretical and empirical understandings. Many studies are limited to single documented events (hurricane, drought, etc.) or natural resources (e.g. rainfall), and the analysis compares 'before' and 'after' situations (Findley 1994; Paul 2005). This is a weakness in the literature, merely capturing snapshots of movement rather than incremental migratory responses (Piguet 2010).
Thus far discussions have largely been through the lens of the natural sciences (Massey et al. 2010; Morrissey 2009), often identifying community response to the impacts of climate change as a direct function of exposure (IPCC 2007; McLeman and Hunter 2010). Polarisation between environmental sciences and migration studies (Castles 2011; Gemenne 2011; Morrissey 2009) helps perpetuate oversimplified accounts of how ecological changes are interlinked with mobility (Bettini and Andersson 2014). This paper seeks to leverage lessons from migration studies to inform a debate that is heavily dominated by environmental scholars, with the aim of helping researchers to explain better the distinctive character of migration in the context of climate change. Because adaptation is widely seen as a matter of environmental policy, we argue that such policy needs to account for all dimensions of migration. We contend that not only do the situations of migrants need to be considered, but also those of the communities of origin and of destination. This goes beyond direct impacts (e.g. of remittances) to include indirect effects on wider economic development, social growth, health outcomes, power structures, inter alia (de Haas 2010; Barbieri and Confalonieri 2011; Abdurazakova 2011). Furthermore, potential maladaptive effects on all sides of migration systems must be considered holistically.

Migration is understood in broad terms, given a diversity of types of internal and cross-border migration and variable accompanying effects on individuals and households. Internal migration is likely to represent the majority of migrations related to climatic and environmental changes (Hugo 1996), although international migration is currently the primary preoccupation of policymakers (UN DESA 2013). We posit that researchers should not limit their attention to any one cause of migration, in order to encompass the outcomes of all types of migration, whatever their reasons. While we focus on the social, economic and political outcomes of migration, which do imply a productive use of available resources, we are unable to consider fully the long-term ecological outcomes of migration. However, this is undoubtedly a critical aspect of the sustainability of migration flows, as is the long-term sustainability of healthy and productive environments in the destination and origin regions (cf. Hugo 1996; Carr 2009).

Our key framing question is the following: adaptation by migration for whom? First, we endeavour to define adaptation in this context. Next, we provide an overview of the environmental migration literature ${ }^{1}$, and follow this with a discussion of the methodological challenges facing researchers in investigating the linkages between environmental and climatic changes and migration. Finally, using noteworthy pieces from among the most directly relevant empirical and conceptual 
work from across migration studies, we discuss the merits and challenges to answering our framing question from each of three possible vantage points: the migrant, the community of origin, and the community of destination. We aim to weigh the essential characteristics, advantages and disadvantages of each approach in order to support future qualitative and quantitative research. While we recognise that these three 'vantage points' do not exist in isolation from one another in practice, we attempt to use this framework as a conceptual guide. In the interest of answering the key question, this paper emphasises the impacts of migration rather than its causes.

In the final section we stress that migration in general, and not only migration triggered in part by environmental changes, can have an impact on adaptation. We recommend that research limits be pressed beyond the superficial category of a migrant whose mobility appears to be directly related to environmental changes (Foresight 2011; IOM 2011). Research would benefit from approaches that are more concurrent with the nuance and long time scale of the impacts of climate change. In the concluding section, we suggest combining methods and addressing technical challenges with this approach. To assist this, Table 1 lays out, in narrative form, four approaches we identify in this text; three vantage points and a combination of methods.

\section{Defining adaptation}

The concept of adaptation emerged from the world of evolutionary biology as a dynamic, nondirectional, longer-term phenomenon (Williams 1966, vii). It has since been applied in the social and political sciences, notably, in the case of cultural and social exchange and adaptation (Chhetri 1987). The Intergovernmental Panel on Climate Change (IPCC) defines adaptation thus: 'In human systems, the process of adjustment to actual or expected climate and its effects, which seeks to moderate harm or exploit beneficial opportunities' (IPCC 2014).

Environmental changes have the potential to erode resilience and adaptive capacities, modifying not only the number of migrants but also the characteristics of pre-existing patterns. Positive adjustments are produced through two mechanisms. First, migrants can contribute to recovery following unavoidable shocks. Second, migration may increase adaptive capacities, defined as the abilities of people and societies to transform structure, function, or organisation to manage better their response to weather hazards and other negative changes (IPCC 2012, 72). Migration may not be the first or only adaptive strategy chosen or, indeed, the most appropriate (Brown 2008). People move short and long distances within the larger frame of their responses to the world around them, an evolving relationship largely shaped by subjective and nonenvironmental factors (Faist and Shade 2013). Perceptions, cultural values and norms are paramount. The perceived ability to employ adaptation strategies successfully may be as important as the objective ability (Grothmann and Patt 2005).

Migration can be a 'successful' adaptation strategy if it can increase the ability to rely on existing household resources (Tacoli 2011b; Warner and Afifi 2014). Adaptive actions are non-linear, may change over time, and are not always necessarily positive. Short-term coping strategies that mitigate harm may be seen as adaptive, but in many cases have proven to be maladaptive in the long term. Maladaptation is defined as an action taken ostensibly to avoid or reduce vulnerability to climate change, but that impacts adversely on, or increases, the vulnerability of other systems, sectors or social groups (Barnett and $\mathrm{O}^{\prime}$ Neill 2010). Both direct and indirect vulnerability to climate-related pressures are important (Magnan et al. 2016). Of note are adaptation measures that may simply reduce in situ pressures by displacing them onto another ecologically or socioeconomically connected 'system'; that is, communities of origin or destination (cf. Juhola et al. 2016; Magnan et al. 2016).

\section{State of the art}

In fragile environments, migration is essential in preserving life and satisfying basic needs. Recent figures suggest that since 2008, an average of 26.4 million people are displaced every year by natural hazard-induced disasters (IDMC 2015). In addition, environmental degradation, exacerbated by climatic changes, can erode livelihoods to a point of rupture. Numerous case studies link increased mobility to periods of environmental stress (Tacoli 2011a; Ginnetti et al. 2013), but socio-economic factors are often the proximate causes of vulnerability (Ginetti et al. 2013). Outside evacuation scenarios, it is important to consider why households perceive themselves to be imminently at risk. Ezra and Kiros (2001), for example, demonstrated through a multilevel analysis of 2000 households in 40 villages in Ethiopia that perceived local vulnerability to a food crisis was a key factor in out-migration.

Recent empirical observations highlight migration as a powerful adaptation strategy for populations faced with environmental and climate changes (Bardsley and Hugo 2010; Black et al. 2011a; McLeman and Smit 2006). In the underpinnings of the New Economics of Labour Migration (NELM) approach, migration is understood as a risk management strategy adopted at the household level (Stark and Levhari 1982; Lucas and Stark 1985). Migration scholars conclude that among rural 


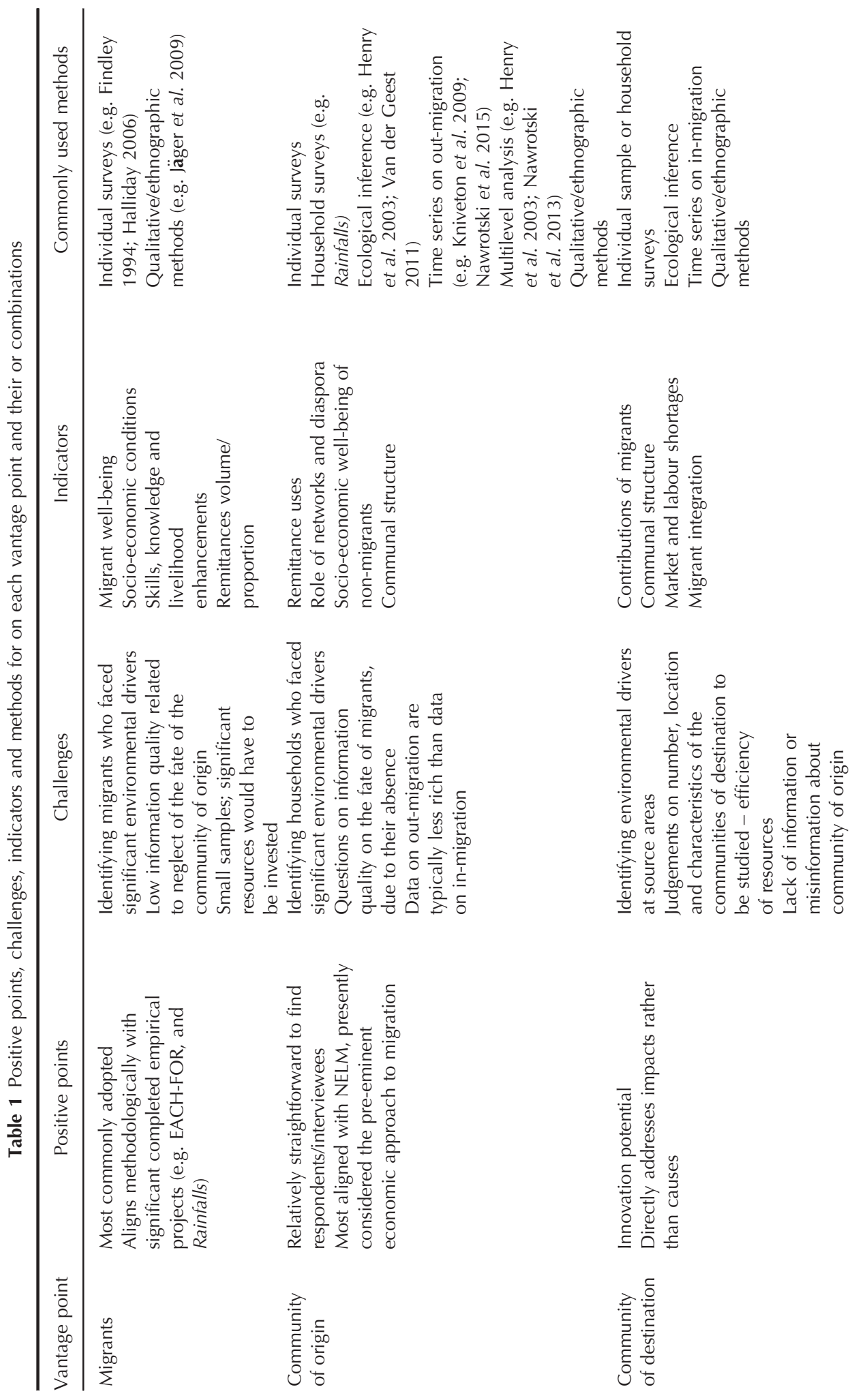




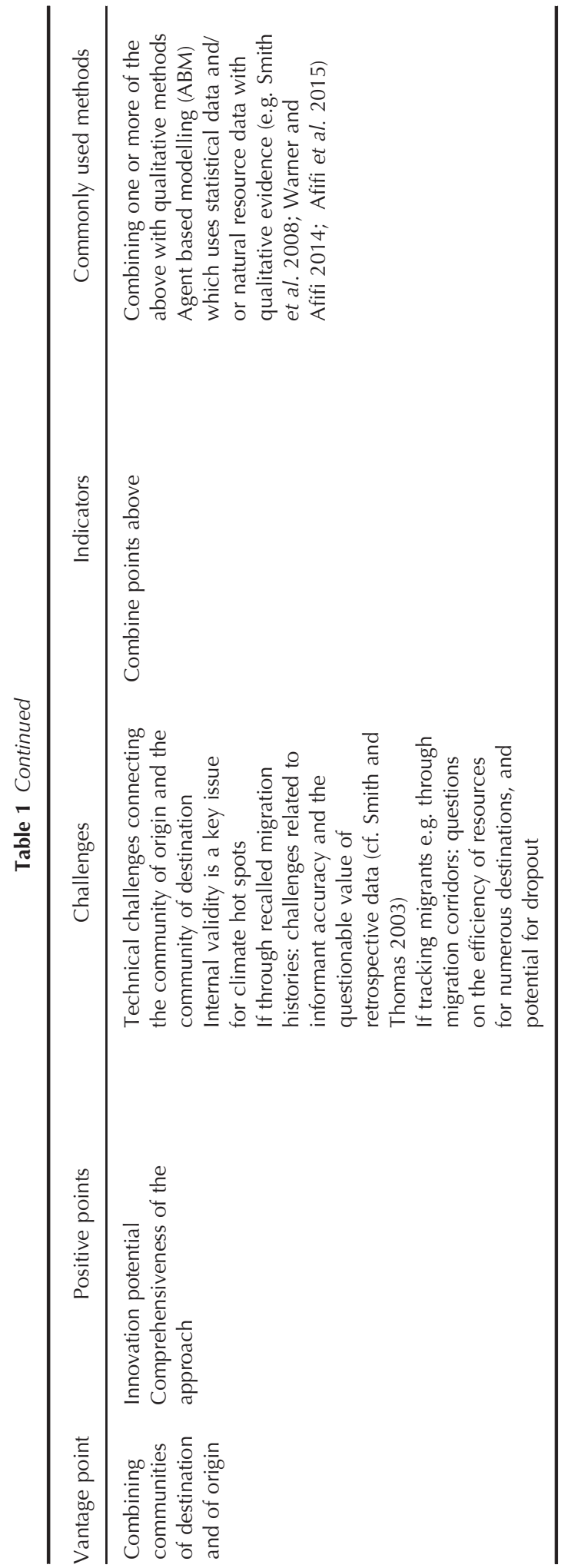

households in particular, dependent on natural resources for household production and consumption (Obokata et al. 2014), internal and cross-border migration can be employed to address income gaps and serve as an informal insurance strategy (Lee 1966; Stark and Levhari 1982; Lucas and Stark 1985; Gubert 2002; Foresight 2011). Migration is not necessarily a strategy of last resort (Hampshire 2002), but is often a voluntary decision taken as part of longer-term strategies aimed at building capacities to confront unfavourable conditions (Jäger et al. 2009). In 1966, Wolpert showed that the largescale internal migration in the US in the 1930s during the 'Dust Bowl' was an adjustment to environmental stress. Rather than a migration en masse, however, the timing and outcomes of migration in this period are distinguished by capital endowments, as a function of household resilience (McLeman and Smit 2006).

Perhaps unsurprisingly, empirical studies produce variable and context-specific signals. Social and political components of exposure and sensitivity to environmental factors evolve (Turner et al. 2003); individual attributes in the makeup of a household vary; and the occurrence of natural hazards and the availability of natural resources are themselves changing, in accelerated and unpredictable ways due to climate change (Stocker et al. 2013). Using a multilevel approach to migration histories in Burkina Faso from 1960 to 1998, Henry et al. (2003) demonstrate that people from drier regions are more likely to engage in both temporary and permanent migration to other rural areas, but the likelihood of short-term moves to distant destinations decreases when rainfall is scarcer, due to more limited household resources. Comparing time series of north-south internal migration and average annual rainfall in Ghana, Van der Geest (2011) suggests that migration can be reduced at times of the most pronounced environmental stress. He emphasises that this behaviour must be seen as part of the 'normal' internal and temporary migration patterns in the region, which serve a traditional lifestyle that is routinely tested by adverse conditions. Jónsson (2010) echoes this notion in her review of case studies of international and internal migration related to drought, desertification and soil degradation in the Sahel. Highlighting the role of pre-existing migration patterns and routes in these movements, she furthermore underlines that these patterns are manifest outcomes of social and cultural considerations.

An important element of the household migration decision-making process appears to be the disposition of various capitals required to migrate. A number of studies demonstrate a $U$-shaped relationship between migration flows and deviation from average rainfall variability, highlighting that the capacity to migrate varies with (changing) household economic resources (Feng et al. 2010; Nawrotzki et al. 2013 2015). Similarly, in an analysis of the drought-prone state of 
Durango in Mexico between 1951 and 1991, increased rainfall is positively correlated with migration to the US (Kniveton et al. 2009). During times of relative plenty of natural resources, households are able to free up the resources necessary for a family member to migrate. During times of peak environmental stress, households lacking the resources to migrate are less mobile, and choose to prioritise basic necessities. The Where the Rain Falls project (hereafter Rainfalls) takes the link between rainfall patterns and human mobility further, distinguishing household 'profiles' of environmental migration in eight countries (Warner and Afifi 2014; Afifi et al. 2015). Rainfalls suggests that while the decision of resource-dependent households to invest in a household member migrating may be correlated with rainfall, the 'success' of migration is often related to contextual conditions and household attributes preceding movement.

Empirical studies thus suggest that migration is a complex and nuanced phenomenon. In public debates, however, migration remains mostly presented as the undesirable outcome of a failure to adapt. In debates around the UN Framework Convention on Climate Change (UNFCCC), emphasis is often placed on displacement of at-risk populations as a forgone conclusion. The presentation of migration as problematic is evidenced by a policy focus on influencing the modalities, volume and geographic bounds of migration, rather than delivering on the development potential of migration (DFID 2013; Black et al. 2011b). Misconceptions and mounting distrust of migrants and asylum seekers contribute to this view (Bosswick 2000; Morrissey 2012).

Such a disconnect between empirical research and public debate is likely at best to induce governance and institutional structures poorly suited to respond to the challenges and opportunities presented (Blocher 2016), or at worse to promote policymakers to support maladaptive policy responses aimed at preventing migration (Black et al. 2011b). This article attempts to inform evidence-based policymaking by suggesting conceptual and methodological approaches for future studies.

\section{Adaptation for whom? Three vantage points to assess}

We explore migration impacts against a framing question: adaptation by migration for whom? Three population groups need to be considered: the migrants themselves, the community of origin, and the community of destination.

\section{For the migrants themselves}

Traditionally it is envisaged that migrants adapt themselves to environmental influences, and this is usually manifested in one of two ways according to the literature. First, migration can thus serve as a response when needs cannot be satisfied in situ, whether there are immediate needs precipitated by a 'tipping point' at which habitation in the home area is no longer tolerable, as identified by residents in Bolivia, Senegal and Tanzania, for example (Tacoli 2011a). Interviewees who identify environmental factors in their decision to migrate often refused to be considered as victims, but insisted on their resourcefulness and proactivity (Farbotko 2005; Gemenne 2011).

Second, migrants also seek access to improved socio-economic status. Indeed, migrants often enjoy greater access to employment, services, and other life opportunities. The multi-country 'Environmental Change and Forced Migration Scenarios' (EACH-FOR) project, a pioneering project which produced a number of empirical studies specific to environmental migration, concluded that in many contexts, apparently successful migrants - a self-selecting group - were the young and socially mobile, who are able to enjoy relatively improved status during migration or upon return (Stark and Taylor 1989 1991; Jäger et al. 2009). In some contexts, migration constitutes an important rite of passage into adulthood as well as an affirmation of household and personal success or prestige (Jónsson 2010 2011). Such insights have since been confirmed by numerous other empirical studies. For many women in post-Soviet countries, migration has often provided new opportunities for greater autonomy, financial control and self-confidence, and also promotes a better balance between the sexes (Abdurazakova 2011).

Migration is, however, a strategy entailing potential risks. In Ghana and Tanzania, for example, it has been characterised as an 'erosive' or maladaptive coping strategy for vulnerable households (Warner and Afifi 2014). Migrants often suffer a relatively lower socioeconomic status than their hosts, and when compared with their previous status in their community of origin (Czaika and de Haas 2012). Migrants face barriers to obtaining employment, access to adequate and dignified living conditions, and security of tenure. Migrants face serious pressures to succeed. Remittances may represent a significant proportion of a migrant's income, leaving them in relative poverty. Anecdotes suggesting that migrants take out loans to visit their families and make shows of wealth are not uncommon, suggesting families may be unaware of the poor conditions in which a migrant is living.

Testing adaptation of the migrants themselves often relies on various indicators of individual wellbeing. Many studies to date have considered the process leading to migration as well as the relative success of migrants in the area of destination (cf. Halliday 2006; Jäger et al. 2009). However, this is a one-sided view. Concretely, migrants may inaccurately represent or be unaware of the situation of their potentially idealised community of origin. Furthermore, non-migrants and community members unable to migrate are underrepresented in these studies, although to 
consider the adaption of the community overall, those left behind are important (Black et al. 2011a).

\section{For the community of origin}

Literature on migration and development weighs the outcomes of migration as a meaningful development strategy for the region of origin, against potential negative effects on the origin areas (cf. de Haas 2010). Communities are influenced either by the migrants' absence or by the links they maintain. At the most basic level, migration can lessen strain on limited resources while alleviating other risks related to overpopulation; this offers those who stay better chances for survival (Mink 1993; Scheffran et al. 2012). Sending a family member out of an area with low access to capital markets allows a household to overcome barriers to production and income (Taylor 1999).

On the other hand, migration can result in deterioration of the workforce and assets amongst those who stay. People who choose not to, or who are unable to, migrate suffer considerably from the departure of others. For example, women are often left with the burden of care for elderly relatives and children. They may suffer isolation, deprivation and the emotional costs and fears of migrant loved ones not returning (Abdurazakova 2011).

The role of migrant networks and personal linkages for the economic and social development of origin areas is significant (Chhetri 1987; Adger 1999; Gubert 2002; de Haas 2007 2010). The commonest intervention for such individuals and networks are the financial remittances sent to relatives back home on a regular basis, which can greatly improve the resilience of the latter to environmental changes and shocks. These transfers play a crucial role in poverty alleviation and development: they are larger and more stable capital flows than overseas development aid or foreign direct investment (Yang and Choi 2007). In addition, social and political remittances the skills, knowledge, and behaviours migrants transfer between receiving and sending areas, along with political and civic practices, bargaining, and identities - are critical to providing the know-how and connections helpful for development in the areas of origin (Barnett and Webber 2010; Levitt and Lamba-Nieves 2011; Asian Development Bank 2012). Transfers of financial, social, and intellectual capitals can foster adaptation in three main ways identified below.

First, they can bolster capital investments and income-generating activities. Household by household, migration is a way of securing a source of revenue in times of hardship. In addition, remittances can support agricultural and nonagricultural investment. In aggregate, they foster a more resilient agriculture and are instrumental in the diversification of rural economies (Yang and Choi 2007; Barnett and Webber 2010). In some contexts, the poorest households are those that do not receive remittances (Tacoli 2011a; Milan et al. 2015). A study conducted in parts of Uzbekistan and Tajikistan found that household incomes deriving from remittances were used mainly for durable goods, business investment, health, education and family traditions (Abdurazakova 2011).

Second, remittances can provide support in the wake of disasters. Natural hazard-induced disasters and humanitarian crises usually trigger waves of solidarity among emigrant groups, which organise themselves to provide relief efforts in the immediate aftermath (Yang 2008). A number of studies in Haiti, Jamaica, the Philippines, Viet Nam and Samoa have found that remittances towards these countries increased following disaster events (Paulson and Rodgers 1997; Adger 1999; Foresight 2011). Internal and international diaspora groups may support the livelihoods of communities of origin in the short term (Adger et al. 2002). Diaspora philanthropy can be channelled by formal and interpersonal networks; via NGOs, places of worship, hometown associations, formal and informal alumni groups, and so on. Diaspora networks can also provide political capital. Following Typhoon Haiyan, the Filipino community in the United States lobbied for the Philippines to be granted temporary protection status (although in this case it was not granted, it was a well supported movement) (Grenier 2013).

Finally, remittances can also fund collective adaptation projects. Although there is little evidence of remittances being pooled to fund projects specific to climate change adaptation, the exacerbation of climate change impacts might make this more likely. Migrant networks have been known to mobilise resources following natural hazard events (Asian Development Bank 2012). Such networks also contribute over time by providing resources, information and capacities to help communities deal with environmental changes. In a number of study areas, for example in Bolivia, remittances have provided the bulk of the capital needed for local agricultural development (Tacoli 2011a). Diaspora philanthropy is increasingly being facilitated by the existence of online social networks and the use of new communications technology.

Testing adaptation of the community of origin implies paying attention to communities affected by a high level of out-migration and/or by environmental changes. Research needs to assess the scale and ultimate use of remittances, monetary and otherwise. Remittance income has been shown to have direct effects on the resource base, economic wellbeing and resilience of a community (Adger et al. 2002). Regardless of the type of migration (short versus longterm, internal versus international), a relatively longterm perspective must be adopted. This means that considering whether migration has helped to fulfil basic needs, or to enhance long-term stability, is 
significant in the assessment of migration as adaptation. The use of remittances for investment may widen pre-existing inequalities (Stark et al. 1986), in ways that use of remittance income for consumption may not. In addition, social remittances may be of comparable value to monetary remittances (Levitt and Lamba-Nieves 2011). Researchers could assess the extent to which these skills were acquired abroad, continue to be used upon return, and have been taught to others.

It would furthermore be important to determine whether a labour shortage and loss of skills in the same region was adequately compensated (cf. Tacoli 2011a). Research could assess whether the magnitude of remittances allows, for example, the hiring of day labourers. These dynamics will also depend on the time migrants spend away, and whether the accrued experience of migrants helps the community to build ever-greater capacities.

\section{For the community of destination}

The dominant narrative on the impacts of migration for its destination regions remains one of competition, tension and conflict. According to a United Nations (UN) review of an array of policies of low- and middle-income nations, the proportion with policies to reduce migration to urban centres rose from $51 \%$ in 1996 to $73 \%$ in 2005 (UN 2006). A review of Poverty Reduction as well as Development Strategy Papers across Africa argues that migration is a common 'scapegoat' for a host of broader socio-economic structural issues (DFID 2013), from the spread of crime and HIV/AIDS to land degradation and poverty (Black et al. 2006). Migration is commonly referred to in public discourse as a driver of overpopulation and conflict. However, few studies have been able to identify strong links between resource scarcity, migration and conflict $^{2}$. Casting environmental migrants as failures plays into commonly held pre-misconceptions, at a time in which migrants and asylum seekers are increasingly viewed in a negative light (Bosswick 2000; Oels 2011).

There are nevertheless important and potentially maladaptive migration flows towards regions that are highly vulnerable to the impacts of climate change due to resource scarcity, overcrowding and inadequate infrastructure (de Sherbinin 2007), and to coastal and deltaic cities in particular (de Sherbinin et al. 2014). The increasing scale and frequency of natural hazards, and ineffective disaster warning and response mechanisms, exacerbate risk (Ginnetti et al. 2013).

Migration and development scholars profess the benefits of migration, as a component assisting in a wider socio-cultural phenomenon of adaptation. First, internal and international migration is historically viewed as an adjustment to market imbalances. In growing urban areas in particular, migrants may fill labour and demographic gaps (Ravenstein 1885; Lee 1966; Taylor 1999; Foresight 2011). Migrant populations also create demand for goods and services, including those from their source areas, bolstering economic growth while forging new and stronger trade relationships.

Second, recent work on multiculturalism and migration policies has highlighted the cultural benefits of migration for diversity. The presence of a migrant population which contributes to public debate and social change has dividends for education, inclusiveness and innovation (cf. Massey et al. 1998; de Haas 2007 2010). Social and cultural capitals, noted above, flow in all directions in migration systems.

A final, and related, point is that because of the diversity that accompanies migrant communities, migration acts as a vehicle for transfers of knowledge and technologies, and thus can help spur growth and development (Freeman and Kessler 2008; de Haas 2010). Migrants are a self-selecting group, and may have a more developed entrepreneurial and risk-taking spirit compared with the average population (Jaeger et al. 2010).

\section{Testing the climate change adaptation-migration nexus}

\section{Adaptation for whom? Some recommendations}

More empirical studies are clearly needed. While case studies are limited, quantitative studies are even more so (Piguet 2010; Foresight 2011; Milan et al. 2015). Combining methods could draw upon a range of methods including ecological inference, individual sample surveys, time series analysis, multilevel analysis, agent-based modelling ( $A B M)$, amongst others (cf. Piguet 2010). The impacts of migration in all its forms are relevant to understanding long-term adaptation. These dynamics can be observed by exploring the creation of new social networks among migrants and between communities as well as through the transfer of knowledge, technology, credit and other resources.

Studies examining both areas of origin and destination (e.g. Warner and Afifi 2014) remain relatively few in number. Such an approach is resource intensive and suffers from the existence of various barriers to studying the migration system as a whole. In addition to financial constraints, the marginalisation of migrants, political sensitivities, and privacy and security concerns can also be prohibitive when it comes to tracing individual migrants throughout their journey. In Table 1 we summarise a number of the advantages and challenges of each of the approaches described above. 


\section{Conclusions}

Scholars' opinions diverge over whether the adaptive benefits of migration outweigh the 'costs' to the home communities. In migration studies to date, methodological choices may have inadvertently led to inaccuracies as interview and survey participants reflect false assumptions about their counterparts in the migration process. Distinguishing the effects of migration on areas that may be source, destination and transit areas poses distinct conceptual challenges. These dynamics clearly demonstrate that all of the vantage points of the migration process should be weighed objectively and comprehensively in investigating migratory outcomes. In order to advance the body of knowledge around the migration-environment nexus, it is necessary to develop a better appreciation of how migration, when employed as a strategy to respond to climate change, affects the adaptive capacities of migrants, communities of origin, and communities of destination.

In the sections above, we have attempted to respond to the conceptual and methodological challenges surrounding these questions. A persistent concern is explicitly relating migrants to environmental factors and seeking to identify the latter in situ, due to the multi-causality of migration phenomena and the role of individual perceptions and motivations. Focusing on 'environmental' migration may overlook the role of other forms of migration in increasing the adaptive capacities of participating communities (Gemenne and Blocher 2016). In studying migration in general, and without seeking to embed definitions, complications of pursuing this area of study may be adequately managed. There remains the need for a reference group against which to compare results; whether it be the non-migrants of the migrant-sending households, members of those households not sending migrants, other migrants, or the host community.

In our final section we argue that studies should, where possible, begin from a starting point of examining changes to migration patterns and migrants as part of system-wide effects. Considering migration in the context of climate change requires this perspective in order to ensure that the potential of migration can be understood and delivered. Future empirical studies should seek to provide a means to consider policy approaches that facilitate the positive contributions of the three vantage points, in order to maximise the benefits and minimise the harms of migration. More empirical evidence at micro- and maco-levels is needed to fill the gaps in current knowledge in order to develop common approaches to promote adaptation.

More reflection is also needed to define what constitutes 'successful' migration in the context of adaptation. Examples noted above distinguish 'successful' movements from maladaptation (Warner and Afifi 2014; Afifi et al. 2015 Magnan et al. 2016), but have not addressed the timescales over which one can draw a conclusion. This requires consideration of multiple types and dimensions of vulnerability. What constitutes adaptation for some may represent maladaptation in other parts of the system. Hence, the development of policies which promote migration as adaptation warrants not just a reflection on the beneficiaries of these policies, but also on the indicators of success - and at which points in time they may best be measured; and these reflections need to be properly integrated.

Progress towards these objectives will help dispel assumptions and negative attitudes surrounding migration, which impose normative judgments on changes in migration flows as having some standard form of impact, positive or negative, on either or both the communities of origin and destination communities. This is critical to advancing the academic discourse and political dialogue surrounding migration, which is a precursor to developing measures to assist migrants and nonmigrants as they adapt to changing conditions.

\section{Acknowledgements}

This research was supported by the European Unionfinanced Migration, Environment and Climate Change: Evidence for Policy (MECLEP) project. We thank our colleagues from the MECLEP consortium for their insight and expertise, although they may not agree with all of the interpretations of this paper. We thank two anonymous reviews for comments that greatly improved the manuscript.

\section{Notes}

1 In regards to environmental drivers of migration, the 'CLIMIG' bibliographic database developed by the University of Neuchatel ensured we conducted a comprehensive review: https://environmentalmigration.iom.int/projects/climig.

2 Cf. O'Loughlin et al. (2012), on the non-linear relationship between temperature and conflict in East Africa between 1990 and 2009, and Kelley et al. (2015), on the potential implications of the 2007-10 drought in Syria on the demographic factors contributing to civil unrest.

\section{References}

Abdurazakova D 2011 Social impact of international migration and remittances in central Asia Asia-Pacific Population Journal 26 29-54

Adger W N 1999 Social vulnerability to climate change and extremes in coastal Vietnam World Development 27 249-70

Adger W N, Kelly P M, Winkels A, Huy L Q and Locke C 2002 Migration, remittances, livelihood trajectories, and social resilience Ambio 31 358-66 
Afifi T, Liwenga E and Kwezi L 2014 Rainfall-induced crop failure, food insecurity and out-migration in SameKilimanjaro, Tanzania Climate and Development 6 5360

Afifi T, Milan A, Etzold B, Schraven B, Rademacher-Schulz C, Sakdapolrak P and Warner K 2015 Human mobility in response to rainfall variability: opportunities for migration as a successful adaptation strategy in eight case studies Migration and Development 1-21

Asian Development Bank 2012 Addressing climate change and migration in Asia and the Pacific ADB, Manila

Barbieri A F and Confalonieri U E C 2011 Climate change, migration and health: exploring potential scenarios of population vulnerability in Brazil in Piguet E, Pecoud A and de Guchteneire P eds Migration and climate change Editions de I'UNESCO, Paris 49-73

Bardsley D K and Hugo G J 2010 Migration and climate change: examining thresholds of change to guide effective adaptation decision-making Population and Environment 32 238-62

Barnett J 2001 Adapting to climate change in Pacific Island countries: the problem of uncertainty World Development 29 977-93

Barnett J and O'Neill S 2010 Maladaptation Global Environmental Change 20 211-13

Barnett J and Webber M 2010 Migration as adaptation: opportunities and limits in Climate change and displacement: multidisciplinary perspectives Hart Publishing, Oxford 37-56

Bettini G and Andersson E 2014 Sand waves and human tides: exploring environmental myths on desertification and climate-induced migration Journal of Environment and Development 23 160-85

Black R, Arnell N W, Adger N W, Thomas D and Geddes A 2011a Migration, immobility and displacement outcomes following extreme events Environmental Science and Policy 27 s32

Black R, Bennett S R G, Thomas S M and Beddington J R 2011b Migration as adaptation Nature 478 447-9

Black R, Crush J, Peberdy S, Ammassari S, McLean Hilker L, Mouillesseux S, Pooley C and Rajkotia R 2006 Migration and development in Africa: an overview migration and development series Southern African Migration Project, Cape Town

Blocher J 2016 Climate change and environment related migration in the European Union policy: an organizational shift towards adaptation and development in RosenowWilliams $\mathbf{K}$ and Gemenne $\mathbf{F}$ eds Organizational perspectives on environmental migration Routledge, New York

Bosswick W 2000 Development of asylum policy in Germany Journal of Refugee Studies 13 43-60

Boswell C, Geddes A and Scholten P 2011 The role of narratives in migration policy-making: a research framework British Journal of Politics and International Relations 13 1-11

Brown O 2008 Migration and climate change IOM Research Series IOM, Geneva

Carr D 2009 Population and deforestation: why rural migration matters Progress in Human Geography 33 355-78

Castles S 2011 Concluding remarks on the climate changemigration nexus in Piguet E, Pecoud A and de Guchteneire eds Migration and climate change Cambridge University Press, Cambridge 415-26

Chhetri R B 1987 Migration, adaptation and socio-cultural change: the case of the Thakalis in Pokhara Occasional Papers in Sociology and Anthropology 1 43-72

Clemens M 2014 Does Development Reduce Migration? IZA Discussion Papers 8592 Institute for the Study of Labor (IZA), Bonn (http://EconPapers.repec.org/RePEc:iza:izadps:dp8592) Accessed June 2016

Czaika M and de Haas H 2012 The role of internal and international relative deprivation in global migration Oxford Development Studies 40 423-42

Department for International Development (DFID) 2013 Policy review: attitudes toward migration in African Development Bank Country Partnership Strategy Papers (CPSPS) Sussex Migrating out of Poverty Research Programme Consortium, Brighton

de Haas H 2007 Remittances, migration and social development: a conceptual review of the literature Social Policy and Development Programme Paper 34 United Nations Research Institute for Social Development, Geneva

de Haas H 2008 Migration and development: a theoretical perspective International Migration Institute Working Paper Series No. 9 James Martin 21st Century School, University of Oxford, Oxford

de Haas H 2010 Migration and development: a theoretical perspective International Migration Review 44 1-38

de Sherbinin A 2014 Climate change hotspot mapping: what have we learned? Climatic Change 123 23-7

de Sherbinin A, Schiller A, Hsieh W H and Pulsipher A 2007 The vulnerability of global cities to climate hazards Environment and Urbanization 19 39-64

Ezra M and Kiros G E 2001 Rural out-migration in the drought prone areas of Ethiopia: a multilevel analysis International Migration Review 35 749-71

Faist T and Schade J 2013 The climate-migration nexus: a reorientation in Faist $\mathbf{T}$ and Schade J eds Disentangling migration and climate change: methodologies, political discourses and human rights Springer, Leiden 3-25

Farbotko C 2005 Tuvalu and climate change: constructions of environmental displacement in the Sydney Morning Herald Geografiska Annaler 87B 279-93

Feng S, Krueger A and Oppenheimer M 2010 Linkages among climate change, crop yields and Mexico-US cross-border migration Proceedings of the National Academy of Sciences USA 107 14257-62

Findley S E 1994 Does drought increase migration? A study of migration from rural Mali during the 1983-85 drought International Migration Review 28 539-53

Foresight 2011 Migration and global environmental change The Government Office for Science, London

Freeman G P and Kessler A 2008 Political economy and migration policy Journal of Ethnic and Migration Studies 34 655-78

Gemenne F 2011 How they became the human face of climate change. Research and policy interactions in the birth of the 'environmental migration' concept in Piguet E, Pécoud A and de Guchteneire $\mathbf{P}$ eds Migration and climate change 
Cambridge University Press/UNESCO, Cambridge and Paris 225-59

Gemenne F and Blocher J 2016 How can migration support adaptation? Different options to test the migration-adaptation nexus Migration, Environment and Climate Change: Working Paper Series 1/2016 IOM, Geneva

Ginnetti J, Dagondon B, Villanueva C, Enriquez J, Temprosa F T, Bacal C and Carcellar N L 2013 Disaster-induced internal displacement in the Philippines: the case of Tropical Storm Washi/Sendong The Internal Displacement Monitoring Centre, Geneva

Glantz M 1991 The use of analogies in forecasting ecological and societal responses to global warming Environment 33 10-33

Grenier A 2013 Will Filipinos be granted temporary protected status in the wake of Typhoon Haiyan? Immigration impact (http://immigrationimpact.com/2013/11/22/will-filipinos-begranted-temporary-protected-status-in-the-wake-of-typhoon-ha iyan/) Accessed 15 June 2016

Grothmann T and Patt A 2005 Adaptive capacity and human cognition: the process of individual adaptation to climate change Global Environmental Change 15 199-213

Gubert F 2002 Do migrants insure those who stay behind? Evidence from the Kayes Area (Western Mali) Oxford Development Studies 30 267-87

Halliday T 2006 Migration, Risk, and Liquidity Constraints in El Salvador Economic Development and Cultural Change 54 893-925

Hampshire K 2002 Fulani on the Move: Seasonal Economic Migration in the Sahel as a Social Process Journal of Development Studies 38 15-36

Henry S, Boyle P and Lambin E F 2003 Modelling the influence of the natural environment on inter-provincial migration in Burkina Faso, West Africa Applied Geography 23 115-36

Hugo G 1996 Environmental concerns and international migration International Migration Review 30 105-31

Intergovernmental Panel on Climate Change (IPCC) 2007 Climate change 2007: impacts, adaptation and vulnerability Contribution of Working Group II to the Fourth Assessment Report of the Intergovernmental Panel on Climate Change Cambridge University Press, Cambridge, UK 976 pp

Intergovernmental Panel on Climate Change (IPCC) 2012 Managing the Risks of Extreme Events and Disasters to Advance Climate Change Adaptation: A Special Report of Working Groups I and II of the Intergovernmental Panel on Climate Change in Field C B, Barros V, Stocker TF, Qin D, Dokken D J, Ebi K L, Mastrandrea M D, Mach K J, Plattner G K, Allen S K, Tignor $\mathbf{M}$ and Midgley $\mathbf{P} \mathbf{M}$ eds Cambridge University Press, Cambridge, UK, 582 pp

Intergovernmental Panel on Climate Change (IPCC) 2014 Climate change 2014: synthesis report in Pachauri R K and Meyer L A eds Contribution of Working Groups I, II and III to the Fifth Assessment Report of the Intergovernmental Panel on Climate Change IPCC, Geneva 151 pp

Internal Displacement Monitoring Centre (IDMC) 2015 Global Estimates 2015: People displaced by disasters IDMC, Geneva International Organization for Migration (IOM) 2011 Glossary on migration International Migration Law No. 25 IOM, Geneva
Jaeger D A, Dohmen T, Falk A, Huffman D, Sunde U and Bonin H 2010 Direct evidence on risk attitudes and migration Review of Economics and Statistics 92 684-9

Jäger J, Frühmann J, Grünberger S and Vag A $2009 E A C H$ FOR Synthesis Report EACH-FOR Secretariat, Budapest

Jónsson G 2010 The environmental factor in migration dynamics - a review of African case studies International Migration Institute Working Papers No. 21, Oxford

Jónsson G 2011 Non-migrant, sedentary, immobile, or 'left behind'? Reflections on the absence of migration International Migration Institute Working Papers No. 39, Oxford

Juhola S, Glaas E, Linnér B O and Neset T S 2016 Redefining maladaptation Environmental Science and Policy 55 135-40

Kelley C P, Mohtadi S, Cane M A, Seager R and Kushnir Y 2015 Climate change in the Fertile Crescent and implications of the recent Syrian drought PNAS 112 3241-6

Kniveton D, Smith C, Black R and Schmidt-Verkerk K 2009 Challenges and approaches to measuring the migrationenvironment nexus in Laczko $\mathbf{F}$ and Aghazarm $\mathbf{C}$ eds Migration, environment and climate change: assessing the evidence International Organization for Migration (IOM), Geneva 41-111

Lee E S 1966 A theory of migration Demography 3 47-57

Levitt P and Lamba-Nieves D 2011 Social remittances revisited Journal of Ethnic and Migration Studies 37 1-22

Lonergan S 1998 The role of environmental degradation in population displacement Environmental Change and Security Project Report 4 5-15

Lucas R E B and Stark O 1985 Motivations to remit: evidence from Botswana Journal of Political Economy 93 901-18

Magnan A K, Schipper E L F, Burkett M, Bharwani S, Burton I, Eriksen S, Gemenne F, Schaar J and Ziervogel G 2016 Addressing the risk of maladaptation to climate change WIREs Climate Change 7 646-65

Massey D S, Arango J, Koucouci A, Pelligrino A and Taylor J E 1998 Worlds in Motion: Understanding International Migration at the End of the Millennium Oxford University Press, Oxford

Massey D, Axinn W and Ghimire D 2010 Environmental change and out-migration: Evidence from Nepal Population and Environment 32(2-3) 109-36

Mcleman R A 2014 Climate and human migration: past experiences, future challenges Cambridge University Press, Cambridge

McLeman R A and Hunter L M 2010 Migration in the context of vulnerability and adaptation to climate change: insights from analogues Climate Change 1 450-61

McLeman R A and Smit B 2006 Migration as an adaptation to climate change Climatic Change 76 31-53

Milan A, Gioli G and Afifi T 2015 Migration and global environmental change: methodological lessons from mountain areas of the global South Earth System Dynamics 6 375-88

Milan A and Ho R 2014 Livelihood and migration patterns at different altitudes in the Central Highlands of Peru Climate and Development 6 69-76

Mink S D 1993 Poverty, population and the environment World Bank Discussion Papers The International Bank for 
Reconstruction and Development/the World Bank, Washington DC

Morrissey J 2009 Environmental Change and Forced Migration: A State of the Art Review, Refugee Studies Centre, Oxford Department of International Development, Queen Elizabeth House University of Oxford, Oxford

Morrissey J 2012 Rethinking the 'debate on environmental refugees': from 'maximalists and minimalists' to 'proponents and critics' Journal of Political Ecology 19 36-49

Mortreux C and Barnett J 2009 Climate change, migration and adaptation in Funafuti, Tuvalu Global Environmental Change 19 105-12

Nawrotzki R, Hunter L, Runfola D M and Riosmena F 2015 Climate change as a migration driver from rural and urban Mexico Environmental Research Letters 10114023

Nawrotzki R, Riosmena F and Hunter L 2013 Do rainfall deficits predict U.S.-bound migration from rural Mexico? Evidence from the Mexican census Population Research and Policy Review 32 129-58

Obokata R, Veronis L and McLeman R A 2014 Empirical research on international environmental migration: a systematic review Population and Environment 36 111-35

Oels A 2011 Comparing three theoretical perspectives on climate change as a security issue: from the 'securitisation' of climate change to the 'climatisation' of the security field in Scheffran J, Brzoska M, Brauch H G, Link M L and Schilling J eds Climate change, human security and violent conflict Springer, Berlin 185-205

O'Loughlin J, Witmer F D W, Linke A M, Laing A, Gettelman A and Dudhia J 2012 Climate variability and conflict risk in East Africa 1990-2009 Proceedings of the National Academy of Sciences USA 109 18344-9

Orlove B 2005 Human adaptation to climate change: a review of three historical cases and some general perspectives Environmental Science and Policy 8 589-600

Paul M K 2005 Evidence against disaster-induced migration: the 2004 tornado in north-central Bangladesh Disasters 29 370-85

Paulson D and Rogers S 1997 Maintaining subsistence security in Western Samoa Geoforum 28 173-87

Piguet E 2010 Linking climate change, environmental degradation and migration: a methodological overview Wiley Interdisciplinary Reviews Climate Change 1 517-24

Piguet E 2013 From 'primitive migration' to 'climate refugees': the curious fate of the natural environment in migration studies Annals of the Association of American Geographers 103 148-62

Ravenstein E G 1885 The laws of migration Journal of the Royal Statistical Society XLVIII 167-227

Rosenzweig C and Hillel D 1993 The dust bowl of the 1930s: analog of greenhouse effect in the Great Plains? Journal of Environmental Quality 22 9-22

Scheffran J, Brzoska Kominek J, Link M L and Schilling 2012 Climate change and violent conflict Science 336 869-71

Smith C D, Kniveton D R, Black R and Wood S 2008 Predictive Modelling Forced Migration Review 31, Oxford University Press, Oxford

Smith J P and Thomas D 2003 Remembrances of things past: test-retest reliability of retrospective migration histories Journal of the Royal Statistical Society A 166 23-49
Stark O and Levhari D 1982 On migration and risk in LDCs Economic Development and Cultural Change 31 191-6

Stark O and Taylor E J 1989 Relative deprivation and international migration Demography 26 1-14

Stark O and Taylor E J 1991 Migration incentives, migration types: the role of relative deprivation The Economic Journal 101 1163-78

Stocker T F, Dahe Q and Plattner G K eds 2013 Climate change 2013: the physical science basis Contribution of Working Group I to the Fifth Assessment Report of the Intergovernmental Panel on Climate Change Cambridge University Press, Cambridge, London and New York 1535 pp

Tacoli C 2011a Not only climate change: mobility, vulnerability and socio-economic transformations in environmentally fragile areas of Bolivia, Senegal and Tanzania International Institute for Environment and Development (IIED), London

Tacoli C 2011b The links between environmental change and migration; a livelihoods approach International Institute for Environment and Development, London

Taylor J E 1999 The new economics of labour migration and the role of remittances in the migration process International Migration 37 63-88

Turner B L, Kasperson R E, Matson P A, McCarthy J J, Corell R W, Christensen L, Eckley N, Kasperson J X, Luers A and Martello M L 2003 A framework for vulnerability analysis in sustainability science Proceedings of the National Academy of Sciences USA 100 8074-9

United Nations (UN) 2006 World population policies 2005 Department of Economic and Social Affairs, New York

United Nations Department of Economic and Social Affairs (UN DESA) 2013 International migration policies government views and priorities UNDESA, New York

Van der Geest K 2011 North-south migration in Ghana: what role for the environment? International Migration 49 69-94

Warner K and Afifi T 2014 Where the Rain Falls: Evidence from 8 countries on how vulnerable households use migration to manage the risk of rainfall variability and food insecurity Climate and Development 6 1-17

Warner K, Ehrhart C, de Sherbinin A, Adamo S and Chai-Onn T 2009 In search of shelter - mapping the effects of climate change on human migration and displacement CARE/CIESIN/ UNHCR/UNU-EHS/World Bank, Bonn

Webber M and Barnett J 2010 Accommodating migration to promote adaptation to climate change World Bank, Washington DC

Williams G C 1966 Adaptation and natural selection: a critique of some current evolutionary thought Princeton University Press, Princeton, NJ

Wolpert J 1966 Migration as an adjustment to environmental stress Journal of Social Issues XXII 92-102

Yang D C 2008 Coping with disaster: the impact of hurricanes on international financial flows, 1970-2002 The B.E. Journal of Economic Analysis and Policy 8 1-45

Yang D C and Choi H 2007 Are remittances insurance? Evidence from rainfall shocks in the Philippines The World Bank Economic Review 21 219-48 